Ritrýnd grein birt 31. desember 2020

\title{
Um sveitakennara í Strandasýslu og Húnavatnssýslu $1887-1905$
}

\author{
Bragi Guðmundsson \\ Abstract $\longrightarrow$ Um höfund $\quad$ About the author $\longrightarrow$ Heimildir
}

Greinin sem hér birtist byggir á gögnum um sveitakennara í tveimur sýslufélögum við Húnaflóa; Strandasýslu og Húnavatnssýslu, áður en formlegri skólaskyldu var komið á. Á Pjóðskjalasafni eru varðveittar fræðsluskýrslur frá 1887 vegna styrkumsókna sveitakennara og veita pær dýrmætar upplýsingar sem hægt er að nýta til margvíslegra athugana. Í rannsókninni sem hér er kynnt er áhersla lögð á að grafast fyrir um pá einstaklinga sem önnuðust kennsluna á árunum 1887-1905.

Helstu niðurstöðureruaðsveitakennararíStrandasýslu voru mun færrieníHúnavatnssýslu. Ástæður eru aðallega tvær. Annars vegar var sú fyrrnefnda mun fólksfærri og eins virðist skipulögð sveitakennsla lítt eða ekki hafa farið fram í premur nyrstu hreppum hennar; Árneshreppi, Kaldrananeshreppi og Hrófbergshreppi, en var nokkuð regluleg er sunnar kom. Hlutfall karl- og kvenkennara á Húnaflóasvæðinu var á pari við pað sem gerðist meðal sveitakennara í landinu öllu fræðsluárið 1903-1904. Aftur á móti var hlutfall kvenkennara allmiklu hærra í báðum sýslum sé allt tímabilið 1887-1905 borið saman við landshlutfallið 1903-1904. Sjö af hverjum tíu sveitakennurum í Húnavatnssýslu höfðu hlotið einhverja formlega menntun en 36\% peirra sem kenndu í Strandasýslu. Flestir skólagengnu piltanna sóttu sitt nám í gagnfræða- eða búnaðarskóla en stúlkurnar í kvennaskóla. Bæði kven- og karlkennarar voru heldur yngri á Húnaflóasvæðinu en kollegar peirra á landinu í heild miðað við árið 1901. Allar stúlkurnar voru 34 ára eða yngri og 74\% karlanna. Í heild voru tæp 80\% kennaranna við Húnaflóa á peim aldri. Flestir kennararnir entust illa í starfinu. Vel innan við helmingur karlkennaranna gerðist bændur að aðalstarfi en aðeins $22 \%$ kvenkennaranna urðu húsfreyjur í sveit. Að minnsta kosti fjórir karlar og sex konur gerðu kennslu að aðalævistarfi af peim 102 kennurum sem vitað er um við Húnaflóa á árunum 1887-1905 og nokkur til viðbótar komust nálægt pví.

Efnisorð: Sveitakennarar, sveitakennsla, farkennarar, Strandasýsla, Húnavatnssýsla

\section{Ágrip}

Dessi grein er áformuð sem sú fyrri af tveimur er byggja á gögnum um sveitakennara (nefndust líka umferðar- eða umgangskennarar) í tveimur sýslufélögum við Húnaflóa; Strandasýslu og Húnavatnssýslu, sem hér eftir verður iðulega rætt um í einu lagi sem Húnaflóasvæðið, ádur en formleg skólaskylda var lögleidd árið 1907. Skrásettar upplýsingar eru takmarkaðar við síðustu tuttugu ár tímabilsins en fyrirliggjandi skýrslur eru dýrmætar heimildir sem hægt er að nýta til margvíslegra athugana. Að pessu sinni er áhersla lögð á að grafast fyrir um pá einstaklinga sem önnuðust kennsluna og verða hér eftir nefndir kennarar. Reynt er að komast að pví hvaða fólk leynist á bak við nöfnin sem opinberar skýrslur tilgreina, hvers konar undirbúningsmenntun pað hafði og 
hvort pað gerði kennslu að aðalævistarfi eða ekki. Niðurstöður fyrri rannsókna verða nýttar eftir pví sem tilefni gefast til, aðallega til samanburðar.

Á undanförnum árum og áratugum hefur talsvert verið skrifað um sögu íslenskra fræðslumála til sjávar og sveita, bæði almenn rit og önnur sértækari um afmörkuð viðfangsefni. Umfangsmest pessara rita er Almenningsfraðsla á Íslandi sem kom út í tveimur bindum á árinu 2008 í tilefni hundrað ára afmælis laga um fræðslu barna og hundrað ára afmælis Kennara(há)skóla Íslands. Í fyrstu köflum pess verks segir Loftur Guttormsson frá hvernig alpýðufræðsla próaðist smám saman á Íslandi á átjándu og nítjándu öld og rekur á greinargóðan hátt megindrætti próunarinnar frá skólalausu samfélagi fortíðar til skólaskyldu barna og unglinga sem lögfest var árið 1907. Á peirri vegferð var fyrst komið á takmarkaðri fræðsluskyldu sem heimilum var gert skylt að uppfylla en eftirlit var í höndum sóknarpresta. Forvígismönnum aukinnar og bættrar menntunar mættu margar hindranir sem áttu sér djúpar rætur í sögu, menningu og rótgrónum viðhorfum landsmanna til heimafræðslu sem eins af hornsteinum samfélagsins. Fjárhagslegar hindranir voru einnig miklar pví fátækt var almenn og rótgróin tregða til samfélagslegra útgjalda úr hvort heldur var hreppssjóðum eða fjárhirslum landsstjórnarinnar.

Loftur Guttormsson segir í fyrra bindi Almenningsfraðslunnar að umferðar- eða farkennarar hafi verið mjög fáséðir í íslensku dreifbýli fyrir 1870 (Loftur Guttormsson, 2008b, bls. 40) en eftir að tekið var að veita landssjóðsstyrki til fastra barnaskóla sunnan- og suðvestanlands árið 1878 og síðan víðar tóku fleiri að eygja möguleika (bls. 49-50). Peir möguleikar urðu að veruleika pegar Alpingi sampykkti „árið 1887 að veita samtals 1500 krónum til pess að styrkja „umferðarkennara““ sem leiddi til pess að fyrstu fjórar umsóknirnar úr Húnavatnssýslu um slíka styrki komu fram (Bragi Guðmundsson, 1992, bls. 80). Tveimur árum síðar sampykkti pingið skilyrði fyrir styrkveitingu úr landssjóði sveitakennurum og barnaskólum til handa (Alpingistíðindi 1889 C, bls. 276, 426-427, 461-462; Stjórnartíðindi fyrir Ísland 1889 B, bls. 141).

Pau skilyrði sem sveitakennarar urðu að uppfylla voru að hafa verið ráðnir af hreppsnefnd eða sóknarnefnd og að peir kenndu lögboðnar námsgreinar, pað er lestur, skrift, kristinfræði og reikning, og réttritun að auki. Oftast er óljóst hver hafði frumkvæði að ráðningu en stundum var pað sóknarpresturinn einn sem réði kennara tilstarfa, stundum voru pað einn eða fleiri hreppsnefndarmenn. Styrkbeiðni ásamt nákvæmri skýrslu um kennsluna átti svo að senda viðkomandi sýslunefnd og með skyldi fylgja vottorð sóknarprestsins um framfarir barnanna. Sýslunefnd sendi síðan tillögu um úthlutun styrkja til embættis landshöfðingja. Pað ferli var reglan til 1897 pegar fallið var frá pví að krefjast umsagnar og tillagna sýslunefnda heldur fóru umsóknir kennara beint til landsstjórnarinnar (Bragi Guðmundsson, 1992, bls. 80).

Loftur Guttormsson ræðir nokkuð um hugtakanotkun í Almenningsfreðslunni og pá með tilliti til pess hvenær rétt sé að tala um heimafræðslu, heimiliskennslu eða farskóla. Niðurstaða hans virðist vera sú að farskólahugtakið verði til nokkurn veginn samhliða setningu laga um uppfræðslu barna í skrift og reikningi árið 1880 (Loftur Guttormsson, 2008c, bls. 62-65) en af skýrslum kennaranna við Húnaflóa pann tíma sem pessi grein tekur til er ljóst að orðð var peim fjarlægt og kannski festist pað ekki almennilega í sessi fyrr en með fræðslulögunum 1907 (Lög um fræðslu barna nr. 59/1907). Par voru ítarleg ákvæði um fræðsluhéruð og fræðslusampykktir par sem mætti „ákveða um farskólahald, eftirlit með heimafræðslu, ráðningu kennara, laun peirra, kennslutíma, nauðsynlegar kennslubækur og kennsluáhöld, og yfir höfuð allt, sem að fræðslunni lýtur“ (13. grein).

Á komandi síðum verður frekar rætt um sveitakennara, sveitakennslu og sveitaskóla en farkennara, farkennslu og farskóla og skal pví ekki frekar dvalist við farskólahugtakið, en minnt skal samt á góða skilgreiningu Lofts Guttormssonar á pví í Uppeldi og menntun árið 1992. Par segir meðal annars: 
Hann [farskólinn] tók ekki á sig neina merkjanlega ytri ásýnd í formi sérstakrar byggingar skólahúss - heldur varð hann til á peim bæ par sem farkennarinn hafði lengri eða skemmri viðdvöl. Til viðbótar við börnin sem áttu heima á hlutaðeigandi býli sóttu hann nemendur frá aðliggjandi bæjum, annaðhvort með pví að peir gengu pangað daglega eða var komið par fyrir yfir kennslutímabilið (Loftur Guttormsson, 1992, bls. 207).

Pessi skilgreining fellur prýðilega að pví fyrirkomulagi barnafræðslu sem tíðkaðist víðast í sveitum á sîđustu áratugum nítjándu aldar og fram á pá tuttugustu.

Eðlilegt er að hér sé sagt stuttlega frá fólksfjölda og öðrum ytri aðstæðum við Húnaflóa og meðal annars er birt kort sem sýnir skiptingu sýslnanna tveggja í sveitarfélög og prestaköll um 1900.

Í annarri grein er ætlunin að beina sjónum að ungmennunum sem kennslunnar nutu. Par verður meðal annars svarað spurningum um aldur peirra, fjölda peirra heimila er nemendurnir komu frá og kennslustaði. Pá verða einnig tíndar til stakar upplýsingar um kennsluaðferðir og aðstæður er leynast í umsögnum og skýrslum sóknarpresta sem kennaranna sjálfra auk nokkurra vitnisburða í prentuðum ritum.

\section{Heimildir og rannsóknaraðferð}

Umsóknir um styrki vegna sveitakennslu og skýrslur um hana eru varðveittar í Pjóðskjalasafni Íslands, Landshöfðingjasafni. Fyrstu árin var ekki notað staðlað skýrsluform svo kennarar og/eða sóknarprestar skrifuðu skýrslurnar og eru pær að vonum nokkuð misjafnar að innihaldi og gæðum. Í úrskurði landshöfðingja um styrkúthlutanir, dags. 23. september 1891, segir hann:

Að pví er formið snertir, pá er mörgum bónarbréfunum allmikið ábótavant í peirri grein, og skýrslurnar sumar hvergi nærri ljósar eða fullkomnar, pótt okkur virðist nokkur framför frá pví í fyrra. Eftir atvikum höfum við pó viljað dæma fremur vægt um pessa galla, par sem annars virðist vera ástæða til að veita styrk, svo sem pótt sérstakt vottorð vanti um, að kennarinn sé rétt ráðinn af sóknar- eða hreppsnefnd, ef sennilegt virðist af öðrum atvikum, svo sem framfaravottorðum prestanna, að svo sé í raun og veru (Pjóðskjalasafn Íslands [PÍ], Lh. N.J. Ár 1891. N nr. 636-649).

Prátt fyrir annmarkana fjölgaði umsóknum um styrkveitingar hratt fyrstu árin og úthlutunum sömuleiðis. Árið 1892 barst landshöfðingja 91 umsókn en 1894 voru pær orðnar 136. Pað ár fengu prír kennarar í Strandasýslu styrk og fimm í Húnavatnssýslu. Mun fleiri styrkir runnu til norðlensku héraðanna austan við. Fjórtán styrkir runnu til Skagfirðinga, fimmtán til Eyfirðinga og tuttugu til Pingeyinga. Meiri líkindi voru með tölunum vestanlands. Borgfirðingar og Mýramenn hlutu samtals sjö styrki, Snæfellingar og Dalamenn fimm styrki hvorir, Barðstrendingar níu og í Ísafjarðarsýslu fengu sex sveitakennarar kennslustyrk vegna fræðsluársins 1893-1894 (IÍ, Lh. N.J. Ár 1894. N nr. 730-809).

Meðal styrkhæfu kennaranna átta við Húnaflóa petta ár var aðeins ein kona, Guðrún Ólafsdóttir (1868-1947) í Prestsbakkaprestakalli sem kenndi a.m.k. tvo vetur, 1893-1895. Í skýrslu séra Páls Ólafssonar á Prestsbakka, dags. 17. maí 1894, kemur fram að kennsla Guðrúnar hófst síðasta sumardag haustið 1893 og stóð til 22. apríl vorið eftir. Hún kenndi á fimm stöðum, fjórar til sex vikur á hverjum peirra og kennslustundir voru sex til átta á dag. Nemendur voru 33 talsins á aldrinum átta til sextán ára. Námsgreinarnar voru lestur, skrift, réttritun, reikningur, barnalærdómur (kverið) og biblíusögur. Fáeinir unglinganna fengu að auki kennslu í landafræði og dönsku. Undir lok skýrslu sinnar segist séra Páll hafa prófað 28 nemendur (alla nema pá fimm sem kennt var síðasta mánuðinn) og segist hann telja að framfarir peirra hafi verið „yfir höfuð að tala góðar, og að kennslukonan hafi leyst starf sitt vel og sómasamlega af hendi“ (PÍ, Lh. Nr. XII. Ár 1894-1905. Sveitakennarar Strandasýsla 1894-1905). 
Skýrsla séra Páls með fylgibréfum er nokkuð dæmigerð fyrir umsóknargögn pessara ára. Hún var óformleg og ætla má að honum og öðrum prestum hafi pótt fyrirmæli yfirvalda um skýrslugerðina frekar ógreinileg. Pað breyttist hins vegar brátt pví áđur en kom til umsókna um styrki vegna kennslu veturinn 1894-1895 voru send út stöðluð skýrsluform sem héldust svo óbreytt pann tíma sem rannsóknin tekur til. Pau atriði sem beðið var um að fyllt væru út eru eftirfarandi: Nafn kennara; heiti prestakalls, sóknar eða hrepps; nafn, aldur og námstími hvers nemanda í vikum; dálkar sem merkt var í hvort viðkomandi nemandi tók tiltekna námsgrein eða ekki, auðir dálkar voru fyrir aðrar námsgreinar en pær sem voru prentaðar á eyðublaðið; heiti bæjanna par sem kennsla fór fram; fjöldi peirra sem fengu kennslu á hverjum bæ og hversu margar vikur hvert ungmenni naut hennar; dagsett upphaf og lok kennslutímabils kennarans; samtölur peirra barna sem voru ófermd og peirra sem voru fermd; fjöldi heimila sem börnin komu frá; tafla sem ætlað var að sýna hversu margar kennslustundir fóru á viku í hverja námsgrein; fjöldi kennslustunda á dag (væntanlega klukkutími hver stund); dagsetning og undirskrift kennarans. Aftan á eyðublaðinu var rými fyrir athugasemdir og viðbætur sem kennari vildi gera og par koma stundum fram drjúgar upplýsingar um námsefni, fyrirkomulag kennslu eða annað.

Af framansögðu má sjá að skýrslurnar geyma fjölpættar upplýsingar og úr sumum peirra voru unnar samtölur á vegum landshöfðingjaembættisins sem birtar voru á prenti. Um skólaárin 1888-1892 er hægt að skoða stuttorðar upplýsingar um barnafræðslu og sveitakennslu í Timariti um uppeldi og menntamál (3. árg., bls., 104-112; 4. árg., bls. 94-95; 5. árg., bls. 92-94) en síðan Stjórnartíðindum og Landshagsskýrslum. Gallinn er hins vegar sá að nöfn kennara og pær tölur sem birtar voru segja ekki nema takmarkaða sögu. Annars vegar vegna pess að pær byggja aðeins á upplýsingum um pá kennara sem styrkhæfir töldust og hins vegar vegna pess að pær tilgreina aðeins brot af öllum peim gögnum sem skýrslurnar sjálfar geyma.

Aðrar helstu frumheimildir sem nýttar eru í pessari grein eru manntalið 1901 og úrvinnsla úr pví í Landshagsskýrslum 1903 ásamt skýrslu Guðmundar Finnbogasonar um fræðslu barna og unglinga veturinn 1903-1904. Hún er einstök heimild um sitt efni og er að sjálfsögðu höfð til samanburðar eftir pví sem tilefni eru til (Guðmundur Finnbogason, 1905). Greinarhöfundur velti pví aðeins fyrir sér að láta nægja að fara í saumana á peim gögnum sem Guðmundur notaði og eru varðveitt í Pjóðskjalasafni (PÍ, Lh. Nr. II. 1903-1904. Skýrslur um fræðslu barna og unglinga veturinn 1903-1904. Ísafjarðarprófastsdæmi - Suður-Múlaprófastsdæmi). Рað hefði leitt til pess að aðeins væru skoðaðir peir kennarar sem eru að baki peim tölum sem Guðmundur birtir í sinni skýrslu. Í Strandasýslu voru peir prír, tveir karlar og ein kona, en í Húnavatnssýslu 24, átján karlar og sex konur (Guðmundur Finnbogason 1905, bls. 14-17). Við athugun kom í ljós að karlarnir sem kenndu í Húnavatnssýslu voru í reynd einum fleiri. Á pví er sú skýring að einn kennari, Sigurjón Jónsson á Kollsá, kenndi pennan vetur bæði í Staðarhreppi austan Hrútafjarðar og í sinni heimasveit, Bæjarhreppi vestan fjarðar. Guðmundur hefur viljað forðast tvítalningu á Sigurjóni en fleiri dæmi eru ekki pennan vetur um að sami einstaklingur kenndi í báðum sýslunum.

Pegar hafist var handa reyndust pað mikil gögn fyrirliggjandi allt frá vetrinum 1887-1888 að freistandi var að fara í gegnum allt sem fannst um petta efni í Landshöfðingjasafni og skrá alla einstaklinga sem pau veita upplýsingar um að fengust við kennslu í sýslunum tveimur um tæplega tveggja áratuga skeið, pað er frá vetrinum 1887-1888 til og með vetrinum 1904-1905. Með peirri aðferð næst til mun fleiri kennara en ef aðeins er horft til peirra sem fengu kennslustyrk úr landssjóði pótt næsta víst sé að ýmsir, einkum óstyrkhæfir heimiliskennarar, komi hvergi fram í varðveittum heimildum.

Til pess að draga upp tiltekna heildarmynd var valið að skoða sérstaklega fyrsta skólaárið sem samræmdar skýrslur eru til um, 1894-1895, og síðan fimmta hvert fræðsluár, pað er 1899-1900 og 1904-1905. Til samanburðar er svo fyrrnefnd skýrsla Guðmundar Finnbogasonar sem byggir á hluta gagnasafnsins sem rýnt var. Niðurstöður eru í meginatriðum settar fram með tvennum hætti. Annars vegar er gerð grein fyrir peim sem komu að kennslu í sýslunum tveimur á öllu tímabilinu 1887-1905 og hins vegar verður unnið sérstaklega með fyrrnefnd prjú fræðsluár. Мeð pví fæst bæði heildarsýn á 
kennarahópinn allan tímann en um leið gefst tækifæri til pess að greina hvort og pá hvaða próun átti sér stað frá 1894-1895 til 1904-1905, ef hún var pá einhver.

Á pessari rannsóknaraðferð eru ýmis vandkvæði. Peirra stærst er að erfitt eða jafnvel ómögulegt getur verið að átta sig á hvaða einstaklingar eru að baki peim nöfnum sem birtast í gögnunum pótt vitað sé hvar viðkomandi kenndi. Margt var reynt til pess að hafa uppi á sem flestum og par koma fjölbreytt mannfræðirit við sögu. Með peirra hjálp og leitum á timarit.is tókst að fá vitneskju um marga kennaranna en aðrir eru aðeins nöfn á blaði. Líklegt er að frótt fólk geti bætt par við en höfundi dugðu Strandamenn Jóns Guðnasonar (1955) nokkuð vel um kennara í Strandasýslu og sama er að segja um Ættir Austur-Húnvetninga eftir Guðmund Sigurð Jóhannsson og Magnús Björnsson (1999) um Húnavatnssýslu. Mestu skiluðu samt báðar útgáfur Kennaratals á Íslandi, einkum sú eldri í ritstjórn Ólafs P. Kristjánssonar (1958-1965) en einnig hin yngri í ritstjórn hans og Sigrúnar Harðardóttur (1985-1988). Í báðar útgáfurnar vantar samt mörg sem komu að kennslu á pessum árum, flest um skemmri tíma. Útgefnum bókum til viðbótar var Manntalsvefur Pjóðskjalasafns Íslands drjúgur (www.manntal.is) og loks kom pað höfundi nokkuð á óvart hve ættfræðivefurinn Íslendingabók reyndist gagnlegur (www.islendingabok.is). Sá vefur geymir ekki einasta fæðingar- og dánarár fjölmargra, heldur eru par einnig margvíslegar aðrar upplýsingar sem að gagni komu.

Par sem hér er ekki rúm til pess að birta heildstæða nafnaskrá og fyrirliggjandi persónuupplýsingar um alla pá sem við sögu koma verður látið nægja að setja niðurstöður fram í töflum og síðan um pær fjallað. Fáein dæmi verða pó tekin af nafngreindum kennurum.

Allmikið hefur verið skrifað um barnakennara á Íslandi á peim tíma sem pessi rannsókn tekur til. Auk nokkurra kafla í Almenningsfraðslu á Íslandi sem áđur hefur verið minnst á skal sérstaklega nefnd rannsókn Ólafar Garðarsdóttur (2010) á íslenskum barnakennurum um aldamótin 1900. Sú rannsókn tekur til landsins alls og er studd stökum dæmum. Höfundi pessarar greinar er hins vegar aðeins kunnugt um eina svæðisrannsókn sem nálgast viðfangsefnið að drjúgum hluta til frá svipuðu sjónarhorni og hér. Pað er gert í stórfróðlegri bók Snorra Porsteinssonar, Barna- og unglingafraðsla í Mýrasýslu 1880-2007 (2009). Í henni er kafli um sveitakennara í Mýrasýslu 1888-1909 og til hans verður vísað um samanburð eftir pví sem efni standa til.

\section{Sýslurnar tvær}

Strandasýsla og Húnavatnssýsla voru tvö sýslufélög á peim tíma sem hér er til skoðunar pví Húnavatnssýslu var ekki skipt í tvennt, austur- og vesturhluta, fyrr en með lögum sem sett voru 22. nóvember 1907 (Bragi Guðmundsson, 1992, bls. 140-147). Báðar sýslurnar voru strjálbýlar um aldamótin 1900, landbúnaður var aðalatvinnuvegur en sjósókn nokkuð stunduð á árabátum beggja vegna Húnaflóa. Eiginlegir péttbýlisstaðir voru engir en fáeinir byggðarkjarnar sem allir tengdust sjósókn, siglingum og verslun en með mismunandi hætti. Enginn peirra var sjálfstætt sveitarfélag. Í Strandasýslu voru Hólmavík og Borðeyri stærst en einnig má nefna Kúvíkur við Reykjarfjörð, Gjögur og Norðurfjörð. Í Húnavatnssýslu voru Hvammstangi, Blönduós og Skagaströnd. Samgöngur voru víðast erfiðar nema helst með ströndum fram, á sjó og landi, og margir bæir og byggðarlög einangruð. Fastir barnaskólar voru engir en Kvennaskóli Húnvetninga, stofnaður 1879, fékk fyrst varanlegt aðsetur á Ytri-Ey á Skagaströnd fjórum árum síðar og svo í nýbyggðu skólahúsi á Blönduósi frá 1901.

Land- og náttúrufræðilegar aðstæður í sýslunum tveimur eru ólíkar. Húnavatnssýsla er að stórum hluta láglend, víðlend, votlend og grasgefin, dalir margir og byggðin dreifð. Í Strandasýslu er byggðin að mestu meðfram ströndinni og norðan Bjarnarfjarðar að sýslumörkum í norðri eru gróðurlítil „blágrýtisfjöll, skriðurunnin og sæbrött með hamra á brúnum. ... [Par] er byggðin fremur strjál víðast hvar og nálega hver einasti bær á sjávarbakkanum. Enda er par hvergi um stóra dali að ræða, par sem mikla byggð mætti setja“ (Jóhann Hjaltason, 1952, bls. 7-8).

Báđar sýslurnar gátu verið gjöfular í góðæri, hvor á sinn hátt, en pær poldu illa slæmt árferði eins og reyndin var ítrekað á níunda áratug nítjándu aldar. Pá voru vetrarhörkur miklar, sumur köld, 
hafís tálmaði siglingum og veiðum, grasbrestur var í landi og skepnufellir (Magnús Jónsson, 1957, bls. 227-235). Um áhrif harðindanna hefur meðal annars verið skrifað í sýslunefndarsögu Húnvetninga (Bragi Guðmundsson, 1992, bls. 44-54) og fjölmargar frásagnir eru af bágu ástandi í blöðum frá pessum tíma. Sem dæmi um pað má nefna að einföld leit á timarit.is skilar pví að orðið bjargarskortur kemur um 160 sinnum fyrir í blaðagreinum á síðustu tveimur áratugum aldarinnar. Í Strandamannabók vitnar Pétur Jónsson til frásagnar manns sem flutti úr Árneshreppi árið 1884 og segir að hann hafi látið

svo um mælt, að pegar vel áraði í Strandasýslu, væri sem allar landsnytjar streymdu að hvaðanæva, bæði til lands og sjávar, enda væru landkostir par svo góðir, einkum fyrir sauðfé, að óvíða myndu slíkir á landi hér. En er harðindi dyndu yfir og hafísar legðust að landinu, lokuðu öllum höfnum og skipaleiðum og pektu öll fiskimið, væri sem engin atorka kæmi að haldi, engir viðburðir dygðu, öll sund sýndust lokuð og allar bjargir bannaðar (Pétur Jónsson, 1947, bls. 14).

Pessa ber að minnast pegar litið er til pess að formleg barnafræðsla virðist ekki hafa átt sér stað norðan Steingrímsfjarðar lengstum pess tíma sem hér er fjallað um - og reyndar mun lengur sé litið til útgefinna barnafræðsluskýrslna næstu ára og áratuga (Barnafræðsla árin 1909-1914, 1922; Barnafræðsla árið 1914-15, 1918; Barnafræðsla árin 1916-20, 1920-1923; Barnafræðsluskýrslur árin 1920-1966, 1967). Um pað gefst vonandi tækifæri til pess að fjalla síðar.

Sveitarfélagaskipan var pá mikið frábrugðin pví sem nú er. Í Töflu 1 og Töflu 2 eru nöfn peirra og íbúafjöldi fyrsta nóvember árið 1901 (Hagstofa Íslands, e.d.). Í Strandasýslu er byrjað nyrst, í Árneshreppi, og endað syðst, í Bæjarhreppi við vestanverðan Hrútafjörð. Í Húnavatnssýslu er byrjað vestast, í Staðarhreppi við austanverðan Hrútafjörð, síðan er haldið austur héraðið og endað í Vindhælishreppi sem náði yfir alla strandlengjuna á vestanverðum Skaga og allt að sýslumörkum við Skagafjarðarsýslu. Mannfjöldatölum í núverandi gagnagrunni Hagstofu Íslands og peim sem eru birtar í Landshagsskýrslum ber saman um Strandasýslu en í Húnavatnssýslu munar ellefu einstaklingum sem Hagstofan telur fleiri en Landshagsskýrslur. Sá munur er svo lítill að hann kallar ekki á nein viðbrögð en í meðfylgjandi töflum er farið eftir peim tölum sem Hagstofan birtir.

Áhugasömum um hvar hreppamörk voru áđur en til stórfelldra sameininga sveitarfélaga kom á síðustu árum skal bent á aðgengilega vefsjá ráðgjafarfyrirtækisins Alta (www.vefsja.is). Í henni er sýnd hreppaskipting eins og hún var árið 1950 og var ekki ósvipuð peirri sem var hálfri öld áður að pví undanskildu að nokkrir péttbýlisstaðir höfðu pá skilið sig frá sveitunum og orðið að sjálfstæðum sveitarfélögum. Einnig er í sömu vefsjá sýnd skipan prestakalla í landinu árið 1890. Ítarlegri og nákvæmar upplýsingar um hreppamörk og breytingar á peim eru í riti Lýðs Björnssonar um sögu sveitarstjórna á Íslandi (1972-1979) og um öll framangreind atriði eru greinargóðar upplýsingar í stórvirki Bjarkar Ingimundardóttur um skipan prestakalla, sókna og prófastsdæma svo langt aftur sem vitað er og til samtímans (2019). Í peirri bók er sagt nákvæmlega frá skiptingu landsins í pessar prjár einingar og hvaða breytingar hafa orðiðá peim í tímans rás. Pá eru í bók Bjarkar tilgreindir allir bæir innan sóknarmarka eins og pau voru árið 1847.

Höfundur pessarar greinar setti sig í samband við Alta og spurðist fyrir um hvort fyrirtækið væri tilbúið til pess að setja saman á eitt kort skiptingu prestakalla og sveitarfélaga við Húnaflóa sem myndi miðast við aldamótin 1900. Undirtektir voru góðar og árangurinn má sjá á Mynd 1. Hún sýnir glögglega hversu erfitt getur verið að ræða jöfnum höndum um mismunandi landfræðilegar einingar pví pær geta skarast pótt mörk peirra falli stundum saman, til dæmis í Árneshreppi. Svo tvö dæmi séu tekin um hið gagnstæða náði Tröllatunguprestakall yfir prjá hreppa í Strandasýslu en í Vindhælishreppi í Húnavatnssýslu var eitt prestakall að öllu leyti og hluti tveggja annarra, par af eins utan sýslunnar. 


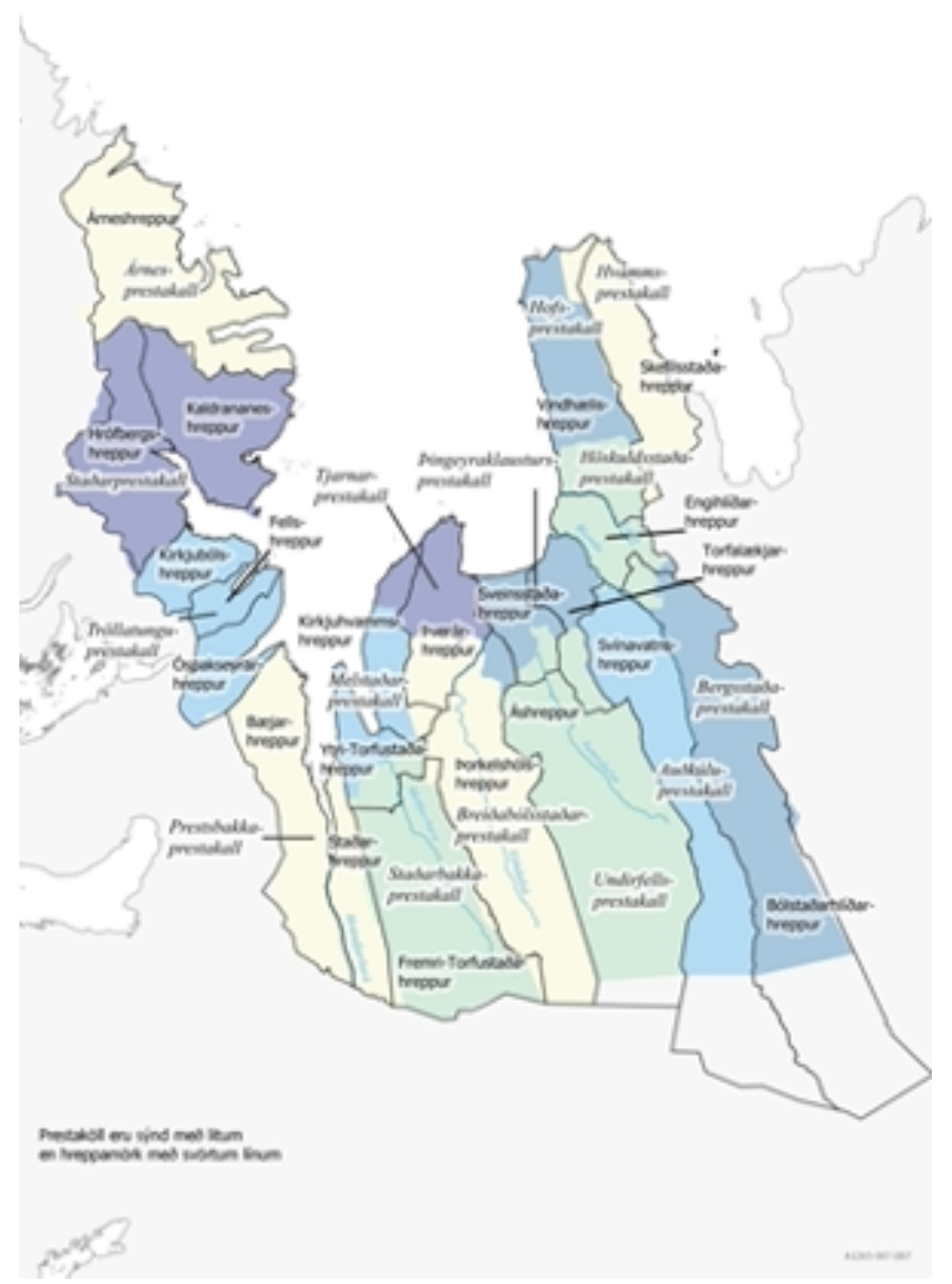

Mynd 1. Hreppar og prestaköll við Húnaflóa um 1900.

Heimild að mynd: Björk Ingimundardóttir, 2019. Kortagerð: Alta ehf.

Í Töflu 1 og Töflu 2 eru tilgreind pau prestaköll sem voru alfarið eða að mestu innan sama sveitarfélags og einnig er tekið fram ef sveitarfélög skiptust á milli prestakalla. Petta er gert vegna pess að skýrslugerð um barnafræðslu var að hluta til í höndum sóknarpresta og skýrslurnar miðuðust við umdæmi peirra en ekki hreppaskiptingu. Prestaköll voru í sumum tilvikum hin sömu og einn eða fleiri hreppar en frá pví eru margar undantekningar svo töflurnar gefa ófullkomna mynd af raunverulegri skiptingu, eins og sést vel á Mynd 1. Sem dæmi má nefna að Staðarprestakalli í Hrútafirði tilheyrðu fjórir innstu bæirnir í Bæjarhreppi vestan fjarðar og í reynd var Staðarsókn hluti af Prestsbakkaprestakalli á árunum 1849-2004 pótt sumir prestar kysu að sitja á Stað frekar en á Prestsbakka (Björk Ingimundardóttir, 2019, 2. bindi, bls. 274). Annað dæmi er að prír bæir nyrst á Skaga tilheyrðu Hvammsprestakalli í Skagafjarðarsýslu og áttu kirkjusókn að Ketu pótt peir væru í Vindhælishreppi í Húnavatnssýslu (Björk Ingimundardóttir, 2019, 2. bindi, bls. 327). 
Tafla 1. Mannfjöldi í Strandasýslu 1901 eftir sveitarfélögum.

\begin{tabular}{llc}
\hline Sveitarfélag & Prestakall/prestaköll & Fjöldi \\
\hline Árneshreppur & Árnesprestakall & 444 \\
Kaldrananeshreppur & Staðarprestakall & 342 \\
Hrófbergshreppur & Staðarprestakall & 201 \\
Kirkjubólshreppur & Tröllatunguprestakall & 251 \\
Fellshreppur & Tröllatunguprestakall & 99 \\
Óspakseyrarhreppur & Tröllatunguprestakall & 109 \\
Bæjarhreppur & Prestsbakkaprestakall & 366 \\
Alls & & $\mathbf{1 8 1 2}$ \\
\hline
\end{tabular}

Heimildir að töflu: Björk Ingimundardóttir, 2019; Hagstofa Ílands, e.d.

Tafla 2. Mannfjöldi î Húnavatnssýslu 1901 eftir sveitarfélögum.

\begin{tabular}{llc}
\hline Sveitarfélag & Prestakall/prestaköll & Fjöldi \\
\hline Staðarhreppur & Staðarprestakall & 187 \\
Fremri-Torfustaðahreppur & Staðarbakkaprestakall & 306 \\
Ytri-Torfustaðahreppur & Staðarbakkaprestakall, Melstaðarprestakall og & 227 \\
& Tjarnarprestakall & \\
Kirkjuhvammshreppur & Tjarnarprestakall & 331 \\
Pverárhreppur & Tjarnarprestakall og Breiðabólsstaðarprestakall & 359 \\
Porkelshólshreppur & Breiðabólsstaðarprestakall & 258 \\
Áshreppur & Undirfellsprestakall & 232 \\
Sveinsstaðahreppur & Undirfellsprestakall og Pingeyraklaustursprestakall & 230 \\
Torfalækjarhreppur & Undirfellsprestakall og Pingeyraklaustursprestakall & 322 \\
Svínavatnshreppur & Auðkúluprestakall & 264 \\
Bólstaðarhliłðarhreppur & Bergsstaðaprestakall og Höskuldsstaðaprestakall & 317 \\
Engihlíðarhreppur & Höskuldsstaðaprestakall & 246 \\
Vindhælishreppur & Höskuldsstaðaprestakall, Hofsprestakall og & 623 \\
Alls & Hvammsprestakall & \\
\hline
\end{tabular}

Heimildir að töflu: Björk Ingimundardóttir, 2019; Hagstofa Íslands, e.d.

Pess skal að lokum getið að skýrslur um barnafræðslu í Strandasýslu eru býsna samfelldar úr prestaköllum Prestsbakka og Tröllatungu, pær eru til muna strjálli úr StaðarprestakalliíSteingrímsfirði og nánast engar úr Árnesprestakalli. Austan Húnaflóa er munur milli einstakra prestakalla og/eða hreppa ekki eins áberandi. Af pessu leiðir að kennararnir austan Húnaflóa verða miklum mun fleiri en kollegar peirra vestan hans. Рað er bæði vegna pess munar sem var á fólksfjölda í héruðunum tveimur en einnig vegna pess að gögn eru nær engin frá nyrðri hluta Stranda. Prátt fyrir petta eru upplýsingar um sýslurnar tvær að miklu leyti aðskildar pegar kemur að tölulegri framsetningu. Раð er gert til pess að sýna stöðuna í hvorri um sig.

\section{Kennararnir}

Í peim gögnum sem rannsökuð voru frá árunum 1887-1905 koma fram nöfn samtals 102 kennara, 73 karla og 29 kvenna. Fjögur peirra kenndu bæði austan og vestan Hrútafjarðar og pví er heildartala 
kennara hærri í hvorri sýslu sem pví nemur. Pau sem komu að kennslu í báðum sýslum voru Guðni Einarsson (1858-1916), bóndi á Óspaksstöðum í Staðarhreppi, Jón Jónsson (1850-1929), lengst bóndi á Drangsnesi, Oddný Finnsdóttir (1871-1913) frá Kjörseyri í Bæjarhreppi og fyrrnefndur Sigurjón Jónsson (1865-1931) á Kollsá.

Að pessu sögðu eru nafngreindir samtals sautján karlar (74\%) sem komu að kennslu á tímabilinu 1887-1905 í Strandasýslu og sex konur (26\%). Í Húnavatnssýslu voru karlarnir 59 (71\%) og konurnar 24 (29\%). Petta er talsvert hærra hlutfall kvenkennara en almennt var í sýslum landsins sé miðað við fræðsluárið 1903-1904 pví pá voru pær 70 af 360 sveitakennurum eða 19\% (Guðmundur Finnbogason, 1905, bls. 16). Sé aðeins litið til pess sama árs í Strandasýslu voru par prír kennarar, par af ein kona, en í Húnavatnssýslu voru konurnar sex af 31 kennara (19\%), nákvæmlega á pari við pað sem gerðist á landinu í heild.

Engin leið er að fá nákvæma vitneskju um starfsaldur kennaranna. Pó er vitað að sumir kenndu aðeins einn vetur og aðrir í áratugi. Peirra á meðal má nefna Strandamennina Sigurgeir Ásgeirsson (1871-1936) á Heydalsá og Sigurjón Jónsson á Kollsá en einnig systurnar frá Kjörseyri, pær Ingibjörgu (1880-1972) og Oddnýju Finnsdætur sem báðar gerðu kennslu að ævistarfi sínu. Austan Húnaflóa áttu peir Eggert Helgason (1830-1910) í Helguhvammi á Vatnsnesi, Frímann Guðmundsson (1828-1904) á Kjalarlandi á Skagaströnd og Halldór Sigurður Halldórsson (1866-1929) á Móbergi í Langadal langan og að pví er virðist farsælan kennsluferil.

Pau nöfn sem hér hafa verið nefnd eru öll að einhverju leyti pekkt og um suma pessara einstaklinga og kennslu peirra hefur pegar verið skrifað. En hvað með kennarahópinn í heild sinni, hverjir voru peir einstaklingar sem eru á bak við heildartölurnar? Til að svara peim spurningum var ráðist í að afla upplýsinga um hvern kennara sem birtist í gögnunum og var víða leitað fanga eins og fyrr er nefnt. Með pví móti tókst að fá pokkalega heildarmynd en engu að síður eru drjúgar eyður sem ekki tókst að fylla, hvað sem síðar verður. - İ textanum hér á eftir munu koma fyrir nöfn nokkurra kennara til viðbótar peim sem pegar hafa verið nefndir til pess að gæða annars purrar tölur nokkru lífi. Hins vegar verður sjaldnast vitnað nákvæmlega til heimilda um persónuupplýsingar eða annað efni sem í mörgum tilvikum eru einföld uppflettiatriði.

Niðurstöður verða hér birtar um prennt. Í fyrsta lagi um menntun kennaranna eins og hún var innan tímaramma rannsóknarinnar, p.e. 1887-1905, í öðru lagi um aldur peirra og loks verður rætt um aðalævistörf viðkomandi aðila. Fyrst skal litið til menntunarinnar, sjá Töflu 3, og eru upplýsingar flokkaðar eftir sýslum og kyni. Samtölurnar neðst í töflunni sýna eilítið hærri tölur en sem nemur fjölda kennara og stafar pað annars vegar af pví að tveir kennarar í Strandasýslu sem fengið höfðu tilsögn hjá presti eru einnig í tölunum um Húnavatnssýslu pví peir kenndu báðum megin Hrútafjarðar. Peir eru taldir með sem kennarar í báðum héruðunum en ekki í samtölunni í síðasta dálki. Hin ástæðan er sú að menntun nokkurra kennara er tvítalin vegna pess að peir voru með tvenns konar nám eða próf að baki. Algengasta tvítalningin af pví tagi eru peir sem bæði höfðu gagnfræðapróf og kennarapróf frá Flensborg í Hafnarfirði (allt karlar) en fleiri tilbrigði eru einnig á ferð. Nöfn íslensku skólanna sjö sem koma fyrir eru vel pekkt en rétt er að ítreka að Kvennaskóli Húnvetninga flutti frá Ytri-Ey til Blönduóss árið 1901 og var rekinn par síðan. Nemendatal pess skóla kom að góðu gagni við að staðfesta upplýsingar um námstíma peirra sem par stunduðu nám (Kvennaskóli Húnvetninga, 1939, bls. 110-148). 
Tafla 3. Menntun sveitakennara í Strandasýslu og Húnavatnssýslu 1887-1905.

\begin{tabular}{|c|c|c|c|c|c|c|c|c|c|}
\hline \multirow[t]{2}{*}{ Menntun } & \multicolumn{3}{|c|}{ Strandasýsla } & \multicolumn{3}{|c|}{ Húnavatnssýsla } & \multicolumn{3}{|c|}{ Samtals } \\
\hline & Kk & Kvk & Alls & Kk & Kvk & Alls & Kk & Kvk & Alls \\
\hline Búfræðingur frá Ólafsdal & 3 & & 3 & 2 & & 2 & 5 & & 5 \\
\hline Búfræðingur frá Hólum & & & & 5 & & 5 & 5 & & 5 \\
\hline Annað búfræðinám & 1 & & 1 & 4 & & 4 & 5 & & 5 \\
\hline Búfræðinám samtals & 4 & & 4 & 11 & & 11 & 15 & & 15 \\
\hline Gagnfræðingur frá Möðruvöllum & 2 & & 2 & 10 & & 10 & 12 & & 12 \\
\hline Gagnfræðingur frá Flensborg & & & & 9 & & 9 & 9 & & 9 \\
\hline Annað gagnfræðanám eða sambærilegt & 2 & & 2 & 1 & & 1 & 3 & & 3 \\
\hline Gagnfræðanám samtals & 4 & & 4 & 20 & & 20 & 24 & & 24 \\
\hline Kvennaskólanám á Ytri-Ey og Blönduósi & & & & & 15 & 15 & & 15 & 15 \\
\hline Annað eða ótilgreint kvennaskólanám & & 1 & 1 & & 5 & 5 & & 6 & 6 \\
\hline Kvennaskólanám samtals & & 1 & 1 & & 20 & 20 & & 21 & 21 \\
\hline Kennarapróf frá Flensborg & & & & 4 & 1 & 5 & 4 & 1 & 5 \\
\hline Kennarapróf frá Noregi & & & & & 1 & 1 & & 1 & 1 \\
\hline Stúdentspróf frá Lærða skólanum & & & & 1 & & 1 & 1 & & 1 \\
\hline Tveggja vetra nám í Lærða skólanum & & & & 1 & & 1 & 1 & & 1 \\
\hline Skipstjórapróf frá Stýrimannaskólanum & & & & 1 & & 1 & 1 & & 1 \\
\hline Nám í kjóla- og karlmannafatasaumi í Rvík & & & & & 1 & 1 & & 1 & 1 \\
\hline Ótilgreint nám í Reykjavík & & & & 1 & & 1 & 1 & & 1 \\
\hline Tilsögn hjá presti & 2 & & 2 & 4 & & 4 & 6 & & 4 \\
\hline Hjá sveitakennara & & & & 1 & & 1 & 1 & & 1 \\
\hline Heimafræðsla & & 1 & 1 & & & & & 1 & 1 \\
\hline Sjálfsnám & 1 & & 1 & 8 & & 8 & 9 & & 9 \\
\hline $\begin{array}{l}\text { Ótilgreint til loka barnafræðsluárs } \\
\text { 1904-1905 }\end{array}$ & 8 & 4 & 12 & 11 & 3 & 14 & 19 & 7 & 26 \\
\hline Annað og ótilgreint nám samtals & 11 & 5 & 16 & 32 & 6 & 38 & 43 & 11 & 52 \\
\hline Alls & 19 & 6 & 25 & 63 & 26 & 89 & 82 & 32 & 112 \\
\hline
\end{tabular}

Heimildir að töflu: Kennaratal og ýmis önnur mannfraðirit; Pjóðskjalasafn Íslands, tilgreindar heimildir i heimildaskrá.

Prátt fyrir að upplýsingar vanti um menntun 26 kennara af 102 (26\%) má ýmislegt áhugavert lesa út úr töflunni. Par má fyrst nefna pann mikla mun sem er á sýslunum tveimur. Ekkert er vitað um bóklegan undirbúning liðlega helmings kennara í Strandasýslu eða tólf kennara af 23 (52\%). Í Húnavatnssýslu eru samsvarandi tölur 14 af 83 eða 17\%. Pegar grunngögn eru rýnd sést að hvorki hefur tekist að afla neinna upplýsinga um fjóra peirra sem kenndu í Strandasýslu né jafnmarga í Húnavatnssýslu eða átta samtals. Eftir eru átján kennarar sem vitað er hverjir voru en engir vitnisburðir hafa fundist um að peir hafi hlotið skilgreinda menntun af neinu tagi og verður að telja líklegt að flestir peirra hafi aðeins notið heimafræðslu og/eða sjálfsmenntunar eftir pví sem kostur var. Rétt er að benda á að mörk heimafræðslu og sjálfsnáms eru afar óljós ef pau voru pá einhver. 
Annað atriði er hve kyngreindur undirbúningur kennaranna var. Konurnar nýttu sér aðeins fjórar námsleiðir utan heimilis, langflestar kvennaskóla- eða hússtjórnarnám (hér eftir aðeins kallað kvennaskólanám). Karlarnir höfðu um fleiri námsleiðir að velja og fleiri skóla, p.e. til búfræði- og/ eða gagnfræðaprófs. Petta endurspeglar pað að konur höfðu færri formlega menntunarmöguleika fyrstu áratugina eftir að tekið var að stofna almenna skóla fyrir ungmenni. Fyrstir slíkra skóla voru kvennaskólar um og eftir miðjan áttunda áratug nítjándu aldar og fáum árum síðar urðu til tveir gagnfræðaskólar og fjórir búnaðarskólar. Kvennaskólarnir voru eins og nafnið bendir til eingöngu ætlaðir stúlkum og búnaðarskólarnir voru eingöngu ætlaðir piltum. Gagnfræðaskólarnir voru opnir báðum kynjum en stúlkur voru fáséðar innan veggja peirra fram um aldamót.

Gagnfræðanámið var unnt að sækja í tvær áttir, til skólans á Möðruvöllum í Hörgárdal (stofnaður 1880) og í Flensborgarskóla í Hafnarfirði (stofnaður 1882). Húnvetnsku kennararnir sóttu nokkuð til jafns í pessa tvo skóla en Strandamennirnir tveir fóru norður. Í Töflu 3 sést að kennaradeildin sem stofnuð var við Flensborgarskólann árið 1892 hafði nokkurt aðdráttarafl. Prír Húnvetninganna (allt karlar) tóku kennaranámið að loknu gagnfræðaprófi og sá fjórði, Porvaldur Guðmundsson (18831961), bóndi í Bólstaðarhlíðarhreppi og síðar kennari á Sauðárkróki, virðist hafa tekið kennaraprófið árið 1904 en ekki er vitað um formlegan undirbúning hans. Fimmti kennarinn frá Flensborg var Ingunn Daníelsdóttir (1872-1943) frá Kolugili í Víđidal. Hún gekk í Kvennaskólann á Ytri-Ey 1893-1895, tók kennaraprófið 1897 og kenndi uns hún giftist um aldamótin og varð húsfreyja á Reykjum í Lundarreykjadal.

Síðasta atriðið sem vekur athygli er hve staðsetning skóla virðist hafa haft mikið að segja um skólagöngu beggja kynja. Hér verður samt að hafa vissan varnagla um uppruna kennaranna. Langflestir peirra áttu vissulega uppruna sinn í sýslunum tveimur en dæmi voru líka um að peir kæmu úr öðrum héruðum til lengri eða skemmri dvalar. Til einföldunar verða allir sem kenndu í Strandasýslu kallaðir Strandamenn og peir sem kenndu austan Húnaflóa Húnvetningar. Að pessu sögðu sóttu Strandamenn sína búfræðimenntun pangað sem skemmst var að fara, í Ólafsdal í Dalasýslu, en Húnvetningar héldu til Hóla í Hjaltadal og raunar víðar. Enn gleggri verður pessi mynd pegar litið er til menntunar kvenkennara á svæðinu. Aðeins ein peirra sem kenndu í Strandasýslu, Ragnheiður Ásgeirsdóttir (1878-1906) á Heydalsá, sótti sér menntun í kvennaskóla (á Akureyri) og um aðra, fyrrnefnda Ingibjörgu Finnsdóttur, segir í Kennaratali (Ólafur P. Kristjánsson, 1958-1965, 1. bindi, bls. 305) að hún hafi lært „bóklegan kvennaskólalærdóm hjá heimiliskennurum." Húnvetnsku stúlkurnar nutu aftur á móti nálægðarinnar við skólann á Ytri-Ey og síðar á Blönduósi. Af peim skóla fór mjög gott orð og augljóst er hversu miklu máli hann skipti fyrir menntun ungra stúlkna í héraðinu. Sumar fóru pó víðar. Vitað er að tvær gengu í Kvennaskólann í Reykjavík og ein í Hússtjórnarskólann í Reykjavík en um tvær til viðbótar segir aðeins að pær hafi verið kvennaskólagengnar en ekki hvar. Sameiginlegt var peim öllum að pær virðast nánast hafa verið sjálfkjörnar til pess að uppfræða börn að námi loknu, langflestar í sinni heimasveit.

Erla Hulda Halldórsdóttir (1997) hefur fjallað ítarlega um stöðu kvenna á nítjándu öld og hún nefnir að kvennaskólarnir hafi opnað peim mikilvæga leið til mennta pótt vissulega sættu sumir peirra nokkurri gagnrýni fyrir pað nám og kennslu sem par fór fram. Augljóst er að kvennaskólarnir skiptu nánast öllu fyrir menntun húnvetnskra kvenkennara og veittu peim stúlkum sem í pá gengu sjálfstraust og áræði til pess að takast á við mikilvæg verkefni utan heimilis.

Pegar framangreindar upplýsingar um menntun sveitakennara við Húnaflóa eru teknar saman verður niðurstaðan sú sem sést í Töflu 4. Peir tveir sem hlotið höfðu tilsögn hjá presti og kenndu eitthvað í báðum sýslum eru hér áfram taldir með báðum megin Húnaflóa en ekki í samanlögðum heildarfjölda kennara. 
Tafla 4. Sveitakennarar við Húnaflóa 1887-1905 skipt eftir menntun.

\begin{tabular}{|c|c|c|c|c|c|c|}
\hline \multirow{2}{*}{ Menntun } & \multicolumn{2}{|c|}{ Strandasýsla } & \multicolumn{2}{|c|}{ Húnavatnssýsla } & \multicolumn{2}{|c|}{ Samtals } \\
\hline & Fjöldi & Hlutfall & Fjöldi & Hlutfall & Fjöldi & Hlutfall \\
\hline Búfræðinám & 4 & $16 \%$ & 11 & $12,4 \%$ & 15 & $13,4 \%$ \\
\hline Gagnfræðanám & 4 & $16 \%$ & 20 & $22,5 \%$ & 24 & $21,4 \%$ \\
\hline Kvennaskólanám & 1 & $4 \%$ & 20 & $22,5 \%$ & 21 & $18,7 \%$ \\
\hline Kennaranám & & & 6 & $6,7 \%$ & 6 & $5,4 \%$ \\
\hline Annað nám & & & 5 & $5,6 \%$ & 5 & $4,5 \%$ \\
\hline Formlegt nám & 9 & $36 \%$ & 62 & $69,7 \%$ & 71 & $63,4 \%$ \\
\hline Tilsögn hjá presti & 2 & $8 \%$ & 4 & $4,5 \%$ & 4 & $3,6 \%$ \\
\hline Tilsögn hjá sveitakennara & & & 1 & $1,1 \%$ & 1 & $0,9 \%$ \\
\hline Heimafræðsla og sjálfsnám & 2 & $8 \%$ & 8 & $9,0 \%$ & 10 & $8,9 \%$ \\
\hline Ótilgreint & 12 & $48 \%$ & 14 & $15,7 \%$ & 26 & $23,2 \%$ \\
\hline Óformlegt og ótilgreint nám & 16 & $64 \%$ & 27 & $30,3 \%$ & 41 & $36,6 \%$ \\
\hline Alls & 25 & $100 \%$ & 89 & $100 \%$ & 112 & $100 \%$ \\
\hline
\end{tabular}

Heildarniðurstaðan er sú að sjö af hverjum tíu sveitakennurum í Húnavatnssýslu höfðu hlotið eitthvert formlegt nám en 36\% peirra sem fengust við sams konar iðju í Strandasýslu. Par eins og annars staðar er mikill munur á milli sýslnanna tveggja.

Engin fyllilega samanburðarhæf rannsókn er til en ef miðað er við skýrslu Guðmundar Finnbogasonar um menntun sveitakennara veturinn 1903-1904 sést að hann telur par 218 sveitakennara af 360 með einhverja formlega menntun, eða 61\%. Á Húnaflóasvæðinu voru pá fjórtán kennarar af 27 með formlega menntun að baki eða 52\%. Erfitt er að segja til um hversu miklar ályktanir má draga af samanburði af pessu tagi en ef rýnt er í tölurnar kemur í ljós að kvennaskólagengnar stúlkur voru 66\% allra kvenkennara við Húnaflóa 1887-1905 og pað hlutfall var nánast hið sama á landinu öllu 1903-1904, 64\%. Búnaðarnám höfðu umræddan vetur 15\% karlkennara að baki á landinu öllu en í Strandasýslu og Húnavatnssýslu var pað hlutfall 18\%. Hvað gagnfræðanám varðar voru samsvarandi tölur nákvæmlega pær sömu, 29\%, bæði á landinu í heild og við Húnaflóa (Guðmundur Finnbogason, 1905, bls. 16).

Snorri Porsteinsson (2009) birtir í riti sínu skrá um sveitakennara í Mýrasýslu á árunum 18872009. Hann byggir að mestu á hliðstæðum gögnum og hér er gert um kennarana við Húnaflóa og ef staðnæmst er við sömu ár í rannsókn hans og hér er gert, 1887-1905, nafngreinir hann 28 kennara í Mýrasýslu, tuttugu karla (71\%) og átta konur (29\%). Snorri vinnur ekki með pað tímabil í útreikningum sínum en frá hausti 1905 til vors 1909 bætast við nöfn tveggja karlkennara og fimm kennslukvenna svo kennararnir verða samtals 35; 22 karlar (63\%) og prettán konur (37\%). Af peim fengu 32 styrk úr landssjóði og að sögn Snorra var menntun peirra eftirfarandi: Kennarar frá Flensborg prír, með stúdentspróf tveir, með gagnfræðapróf sjö, búfræðingar prír, með kvennaskólanám sjö, verið í Mjólkurskólanum á Hvítárvöllum tvær, hjá presti tveir, sjálfsmenntun fjórir, ekki vitað tveir, dvöl við nám og störf erlendis nokkrir. Snorri kyngreinir ekki pessar niðurstöður en gefa má sér að kennarar Mýramanna hafi sótt menntun í svipaðar áttir og kennarar við Húnaflóa (og væntanlega á landinu öllu) gerðu á sama tíma.

Pegar kemur að spurningu um á hvaða aldri kennararnir á Húnaflóasvæðinu hafi verið var notuð sú aðferð að velja prjá barnafræðsluvetur, 1894-1895, 1899-1900 og 1904-1905, sjá Töflu 5. Petta var meðal annars gert til pess að sjá hvort einhver breyting væri greinanleg á pessu stutta tímabili en einnig vegna pess að eftir veturinn 1894-1895 var í fyrsta sinn safnað samræmdum skýrslum um skólahald, eins og áður hefur komið fram. Engin ástæða er til pess að halda sýslunum tveimur 
aðskildum í pessari umfjöllun vegna pess hve fáir kennarar voru í Strandasýslu umrædda vetur, fjórir pann fyrsta, tveir pann næsta og prír hinn síðasta. Samtals eru nafngreindir 48 kennarar í sýslunum tveimur pessa prjá vetur, einn peirra kenndi pá alla (Eggert Helgason í Helguhvammi) og fimm kenndu tvo vetur af premur. Fjóra einstaklinga tókst ekki að aldursákvarða.

Við úrvinnslu eru taldir saman allir kennarar sem kenndu hvern tilgreindan vetur (líka peir fimm sem eru tvítaldir og sá sem er prítalinn, allt karlar) og pannig fæst heildartalan 44, tíu konur og 34 karlar. Fjórtán kenndu fyrsta veturinn, ellefu pann næsta og nítján pann síðasta.

Tafla 5. Aldursskipting sveitakennara við Húnaflóa 1894-1905.

\begin{tabular}{ccc}
\hline Aldur & Fjöldi & Hlutfall \\
\hline Yngri en 25 ára & 15 & $34 \%$ \\
$25-34$ ára & 20 & $46 \%$ \\
$35-44$ ára & 3 & $7 \%$ \\
$45-54$ ára & 1 & $2 \%$ \\
$55-64$ ára & 2 & $4 \%$ \\
65 ára og eldri & 3 & $7 \%$ \\
\hline Alls & 44 & $100 \%$ \\
\hline
\end{tabular}

Niðurstaðan sýnir að 80\% kennaranna voru 34 ára eða yngri. Allar stúlkurnar voru í yngstu tveimur aldurshópunum og 74\% karlmannanna. Kennarahópurinn var pannig heldur yngri en var á landinu öllu árið 1901 sé miðað við niðurstöður Ólafar Garðarsdóttur (2010) og skiptir engu pótt aðeins sé litið til einhvers eins vetrar af peim premur sem hér er slegið saman. Ólöf hefur reiknað út að íslenskir kvenbarnakennarar árið 1901 hafi verið að meðaltali 29,6 ára og karlkollegar peirra 35,8 ára. Samsvarandi tölur fyrir Húnaflóasvæðið eru 26,9 ár hjá kennslukonunum tíu og 34,1 ár hjá körlunum 34. Aldurssamanburður við kennara í Mýrasýslu er ekki mögulegur pví Snorri Porsteinsson (2009) veitir engar upplýsingar um aldur nafngreindra kennara par og reyndar eru persónuupplýsingar um pá fremur litlar og nokkuð handahófskenndar.

Langelstu kennararnir voru Eggert Helgason (1830-1910) í Helguhvammi á Vatnsnesi sem kenndi í áratugi, nánast fram á síðasta dag, og Kristján Magnússon (1837-1910) á Hnjúki í Vatnsdal sem kenndi einnig lengi og allt fram undir andlátið, segir í Kennaratali. Báðir voru sjálfsmenntaðir en fjölhæfir og fengust við margt um ævina.

Yngst kennslukvennanna var Guðfinna Stefánsdóttir (1883-1956) frá Dalgeirsstöðum í Miðfirði. Hún var námsmey í Kvennaskólanum á Blönduósi í tvo vetur, 1901-1903, og hóf kennsluferil sinn strax haustið 1903 í Fremri-Torfustaðahreppi í Miðfirði, tvítug að aldri. Í Kennaratali kemur fram að hún hafi kennt til 1910 en kennsluferli hennar virðist hafa lokið er hún gekk í hjónaband 1912 og varð húsfreyja í sinni heimasveit.

Prír karlkennarar höfðu ekki náð tvítugsaldri er peir hófu að kenna. Peirra yngstur var Garðar Gíslason (1876-1959) frá Pverá í Fnjóskadal. Hann fór sextán ára í Möðruvallaskóla og var par í tvo vetur en varð kennari í Sveinsstaðahreppi aðeins átján ára haustið 1894. Næstu tvo vetur kenndi hann á Húsavík og Akureyri og vann svo við verslunarstörf hjá Magnúsi Sigurðssyni á Grund í Eyjafirði. Garðar varð stórkaupmaður (heildsali) að atvinnu og umsvifamikill innanlands sem erlendis (Gils Guðmundsson, 1988).

Eftirtektarvert er að ungu kennararnir entust frekar illa í starfi. Veturinn 1899-1900 voru fjórir við kennslu sem höfðu verið pað fimm árum áður og veturinn 1904-1905 voru prír við kennslu sem höfðu verið pað fimm árum fyrr. Margt bendir til pess að kennsla hafi verið tímabundið starf, gjarnan að loknu námi, áður en hjúskapur (á einkum við konur) og/eða aðalævistarf tók við. 
Ólöf Garðarsdóttir (2010) setur fram spurningu um hvort kennarastarfið hafi á pessum árum verið ævistarf eða tímabundið. Niðurstaða hennar og áður Lofts Guttormssonar (2008d) er sú að á pessum árum og vel fram á tuttugustu öld hafi fæstir kennarar verið búnir að festa ráð sitt pegar peir hófu kennslu og pað rími vel við að meðalhjúskaparaldur var frekar hár og tiltölulega fá gengu í hjónaband fyrir 25 ára aldur. Pegar pað síðan gerðist hættu flestar konur að kenna en karlmenn voru líklegri til pess að halda pví áfram prátt fyrir lág laun.

Upphafleg tilgáta pess sem hér skrifar var að flestir kennaranna við Húnaflóa hefðu orðið bændur og húsfreyjur í sveit eftir að kennsluári/-árum peirra lauk. Pegar til kom reyndist dæmið ekki svo einfalt og í allmörgum tilvikum er erfitt að ákvarða hvert varð aðalstarf viðkomandi. Samt má fullyrða að í pað minnsta 26 karlar af 82 (32\%) urðu bændur að aðalævistarfi og tíu til viðbótar voru bændur meðfram öðrum hlutverkum, til dæmis sem verslunar- og veitingamenn innan og utan svæðis, kaupfélagsstjórar, einn var pekktur söðlasmiður og annar bókbindari. Pá má reikna með að ýmsir hafi haft fáeinar skepnur meðfram öðrum störfum sér til viðurværis. Um tíu karlkennaranna er ekki vitað hvað varð og einn fór til Vesturheims. Eftir stendur að vel innan við helmingur karlkennaranna tók við búi í sveit og aðeins fjórir peirra urðu kennarar að aðalævistarfi pótt áhöld geti verið um hvort sú tala sé ekki ívið of lág, sbr. pað sem segir hér aðeins síðar.

Hlutfallslega enn færri konur en karlar urðu bændur (p.e. húsfreyjur í sveit) að aðalævistarfi eða sjö af $32(22 \%)$. Að minnsta kosti sex kvennanna voru ógiftar og barnlausar alla ævi. Fimm peirra urðu kennarar að aðalævistarfi og pað var líka ein til viðbótar sem giftist seint og eignaðist ekki barn. Pessar konur gegndu sumar öðrum störfum meðfram, svo sem skólastjórn, póstafgreiðslu og símavörslu. Áhugavert er að tvær kvennanna voru systur, ættaðar frá Kjörseyri í Bæjarhreppi í Strandasýslu. Pað voru fyrrnefndar Oddný og Ingibjörg Finnsdætur. Priðja systirin, Matthildur (1876-1942), var einnig kennari en átti starfsvettvang utan sýslnanna tveggja við Húnaflóa. Athugandi væri að rekja sögu pessara priggja systra og reyna að kortleggja pá áhrifapætti sem höfðu mest að segja um æviferil peirra og starfsval.

Um pær konur sem ótaldar eru er mismikið vitað og tvær peirra ekkert. Nefna má að fimm fóru til Vesturheims, ein varð klæðskeri í Reykjavík, önnur kenndi lengi en giftist fertug og hætti pá að kenna (Guðný Jónsdóttir (1878-1975) frá Galtafelli í Hrunamannahreppi).

Pegar allt er talið gerðu að minnsta kosti fjórir karlar og sex konur kennslu að aðalævistarfi af peim 102 kennurum sem vitað er um við Húnaflóa á árunum 1887-1905 og nokkur til viðbótar komust nálægt pví. Peirra á meðal má nefna Sigurgeir Ásgeirsson (1871-1936), bróður Ragnheiðar kennara. Hann stofnaði og rak lengstum sjálfur merkan barna- og unglingaskóla á Heydalsá á árunum frá 1897 til 1916 (Jón Guðnason, 1955, bls. 155-156; Ólafur P. Kristjánsson, 1958-1965, 2. bindi, bls. 149). Heimildum ber reyndar ekki saman um hvenær unglingaskólinn lagðist af en hér er farið eftir glöggri frásögn Péturs Jónssonar í Strandamannabók (1947, bls. 205). Um skólahaldið á Heydalsá eru drjúg gögn í Pjóðskjalasafni sem áhugavert væri að vinna rækilega úr (PÍ, Stv. D.I. Nr. 342-345). Loks skulu nefndir feðgarnir Frímann Guðmundsson (1828-1904) á Kjalarlandi við Skagaströnd, Frímann Frímannsson (1872-1920), verslunarmaður á Akureyri, og Jakob Frímannsson (18781912), bóndi og kennari á Skúfi í Norðurárdal. Frímann eldri og Jakob voru pekktir kennarar og um pá hefur Magnús Björnsson frá Syðra-Hóli skrifað ítarlega kafla par sem meðal annars er fjallað um aðstæður peirra og kennsluaðferðir (Magnús Björnsson, 1953, 1957a, 1957b).

\section{Lokaord}

Hér hefur verið reynt að draga upp mynd af peim einstaklingum sem sinntu sveitakennslu við austanog vestanverðan Húnaflóa á árunum 1887-1905. Helstu niðurstöður eru í stuttu máli eftirfarandi:

Í fyrsta lagi voru sveitakennarar í Strandasýslu mun færri en í Húnavatnssýslu og pað skýrist bæði af pví að sú síðarnefnda var allmiklu fólksfleiri og að skipulögð sveitakennsla virðist lítt eða ekki 
hafa farið fram í Árneshreppi nyrst í Strandasýslu. Hún var einnig mjög takmörkuð í Bjarnarfirði og við innan- og norðanverðan Steingrímsfjörð en nokkuð regluleg er sunnar kom. Sams konar svæðismunur er ekki eins greinilegur austan Hrútafjarðar og hafa ber hugfast að sveitakennslan náði aðeins til hluta barna og ungmenna prátt fyrir skýr ákvæði um fræðsluskyldu öllum til handa. Hvernig heimafræðslu var framfylgt fyrir pann stóra hóp sem engrar skipulagðrar fræðslu naut hefur ekki verið rannsakað.

Í annan stað var hlutfall karl- og kvenkennara á Húnaflóasvæðinu á pari við pað sem gerðist meðal sveitakennara í landinu öllu fræðsluárið 1903-1904. Aftur á móti var hlutfall kvenkennara allmiklu hærra í báðum sýslum sé allt tímabilið 1887-1905 borið saman við landshlutfallið 1903-1904. Рað er forvitnileg niðurstaða og fátt um augljósar skýringar.

Upplýsingar liggja fyrir um menntun 76 sveitakennara af 102 við Húnaflóa á pví tímabili sem rannsakað var. Mikill munur reynist vera á milli sýslnanna tveggja pví sjö af hverjum tíu sveitakennurum í Húnavatnssýslu höfðu hlotið eitthvert formlegt nám en 36\% peirra sem kenndu í Strandasýslu. Flestir skólagengnu piltanna sóttu sitt nám í gagnfræðaeða búnaðarskóla en stúlkurnar í kvennaskóla, par af fimmtán af 21 í Kvennaskóla Húnvetninga á Ytri-Ey og Blönduósi. Um pá kennara sem engar menntunarupplýsingar eru um er ekki vitað með vissu, en líklegt er að flestir peirra hafi verið sjálfsmenntaðir eins og pað var gjarnan kallað pegar engin formleg menntun var til staðar. Miðað við skýrslu Guðmundar Finnbogasonar 1903-1904 var Húnaflóasvæðið nokkuð undir landsmeðaltali hvað varðar formlega menntun kennara pað staka fræðsluár en hins vegar aðeins yfir pví ef litið er til tímabilsins 1887-1905 í heild miðað við 1903-1904. Á peim athyglisverða mun er skýringa vant.

Fjórða atriðið sem staldrað skal við er aldur kennara. Niðurstaðan er sú að bæði kvenog karlkennarar voru heldur yngri á Húnaflóasvæðinu en kollegar peirra á landinu öllu miðað við árið 1901. Allar stúlkurnar voru 34 ára eða yngri og 74\% karlanna. Í heild voru tæp $80 \%$ kennaranna við Húnaflóa á peim aldri. Samanburður á fræðsluárunum 1894-1895, 1899-1900 og 1904-1905 sýnir jafnframt að kennararnir entust flestir illa í starfi og rímar pað við fyrri niðurstöður um að kennsla hafi verið tímabundið starf sem gjarnan lauk við hjúskap.

Par sem Strandasýsla og Húnavatnssýsla voru báđar dreifbýlar og fyrst og fremst setnar bændum á peim árum sem hér eru til skoðunar, var pað upphafleg tilgáta höfundar að flestir kennaranna hefðu tekið við búi að loknum kennsluferli. Sú tilgáta stóðst illa pví vel innan við helmingur karlkennaranna fór pá leið og aðeins $22 \%$ kvenkennaranna gerðust húsfreyjur í sveit að aðalstarfi. Með vissu er unnt að fullyrða að í pað minnsta fjórir karlar og sex konur hafi gert kennslu að aðalævistarfi af peim 102 kennurum sem vitað er um við Húnaflóa á árunum 1887-1905 og nokkur til viðbótar komust nálægt pví, flest peirra karlar.

Óhætt er að fullyrða að langflestir sveitakennaranna, konur sem karlar, áttu uppruna sinn í sveit. Pau hafa komið úr misstórum fjölskyldum og af einhverjum ástæðum hélt góður meiri hluti peirra að heiman og aflaði sér formlegs náms. Mörgum varð pað fyrsta skrefið í átt frá hefðbundnum hlutverkum innan pess samfélags sem pau áttu uppruna sinn í. 


\section{On rural teachers in the districts of Strandasýsla and Húnavatnssýsla 1887-1905}

From shortly before the middle of the 18th century, Icelandic homes were obliged to provide children with instruction in religion and reading. This obligation was extended in 1880, when writing and arithmetic were added. The homes were supposed to provide the instruction, monitored by parish priests. By the middle of the 19th century, the need for schools for children and teenagers was generally recognized and they were founded one by one, primarily in urban areas. In the countryside, teaching mainly took place in homes and clergymen were supposed to monitor the children's progress. Formal compulsory education was not introduced by law until 1907, with parents previously having been free to choose whether or not they sent their children to school.

Many were concerned about the lack of schools but proponents of improved education often had to tackle obstacles deeply rooted in Icelandic history and culture, as well as in the firm belief that homeschooling was a cornerstone of society. There were also economic hindrances due to the high level of poverty amongst the general population and an ingrained reluctance to use public funds to cover communal expenses. Nevertheless, organised homeschooling was widely established in rural areas in the course of the 19th century, even though it was not available to all children and teenagers.

This is the first of two planned articles based on data regarding rural teachers in two districts in the Húnaflói Bay area; that is, Strandasýsla and Húnavatnssýsla, prior to the formal introduction of compulsory education. The National Archives of Iceland preserve reports from 1887 and onwards that deal with grant applications from rural teachers. These reports provide valuable information that can be used for various observations. This article aims to shed some light on the individuals who were responsible for teaching between 1887 and 1905 and will from now on be referred to as teachers, whether or not they were formally certified as such. An attempt is made to reveal the people behind the names found in the reports, and to find out what their education was and whether or not teaching was their main occupation in life.

The main conclusions are the following:

- There were far fewer rural teachers in the district of Strandasýsla than in that of Húnavatnssýsla. The main reasons for this are, on the one hand, the greater number of inhabitants in the latter district and, on the other, the apparent general lack of organized rural teaching in the Árneshreppur Commune in the far north of the district of Strandasýsla. This was also quite limited in the inner and northern parts of Steingrímsfjörður while it occurred fairly regularly in the southern parts of the district. This regional difference was less prominent in the district of Húnavatnssýsla and it should be kept in mind that rural teaching only reached some children and teenagers despite clear regulations regarding compulsory education for all.

- The proportion of male to female teachers in the Húnaflói Bay area was similar to that amongst rural teachers in all of Iceland in the school year of 1903-1904. However, the proportion of female teachers was considerably higher in both districts if the entire period $1887-1905$ is compared to the general proportion in 1903-1904. This is an interesting finding.

- Information is available regarding the education of 76 of the 102 rural teachers who were active in the Húnaflói Bay area during the examined period. A clear difference appears between the two districts as $70 \%$ of rural teachers in the district of Húnavatnssýsla had some formal education while this only applies to $36 \%$ of the teachers in the district of Strandasýsla. Most of the formally educated boys had studied at secondary school or at an agricultural school while the girls went to domestic schools, but fifteen of the 21 girls attended the Women's School of the district of Húnavatnssýsla at Ytri-Ey and Blönduós. As 
regards the teachers about whom no educational information is available, most of them are likely to have been self-educated.

- When 1901 is taken as a point of reference, both female and male teachers in the Húnaflói Bay area were a little younger than their colleagues elsewhere in the country. All the girls were 34 years of age or younger and this applied to $74 \%$ of the boys. All in all, just under $80 \%$ of the teachers in the Húnafói Bay area were in this age category. A comparison of the school years 1894-1895, 1899-1900 and 1904-1905 also reveals that most of the teachers did not last long in their posts. This is in line with results of previous research which indicate that teaching was a temporary job that the teachers often abandoned when they got married.

- As the districts of Strandasýsla and Húnavatnssýsla were both sparsely populated and primarily inhabited by farmers, the author's initial hypothesis was that most of the teachers would settle on a farm as their teaching careers ended. This hypothesis was not confirmed, as less than half of the male teachers took up farming and only $22 \%$ of the female teachers became farmers' wives. Out of the 102 teachers who are known to have worked in the Húnaflói Bay area in 1887-1905, at least four men and six women can with certainty be said to have made teaching their main occupation in life. A few more came close to falling into this category, most of them male.

Key words: Rural teachers, rural teaching, District of Strandasýsla, District of Húnavatnssýsla

\section{Um höfund}

Bragi Guðmundsson (bragi@unak.is) er prófessor í sagnfræði við Hug- og félagsvísindasvið Háskólans á Akureyri. Hann er með cand. mag.-próf í sagnfræði frá Háskóla Íslands og nám til kennsluréttinda frá sama skóla. Hann er með leyfisbréf sem framhaldsskólakennari og prettán ára starfsreynslu sem slíkur. Bragi hefur unnið að ytra mati á rúmlega tuttugu íslenskum framhaldsskólum. Rannsóknir hans á seinni árum hafa aðallega beinst að notkun grenndaraðferðar við kennslu og íslenskri skólasögu.

\section{About the author}

Bragi Guðmundsson (bragi@unak.is) is professor of history at the School of Humanities and Social Sciences at the University of Akureyri. He holds a cand. mag. degree in history and a postgraduate diploma in teaching from the University of Iceland. He is a licensed upper secondary school teacher and worked in that field for thirteen years. Bragi has been an external examiner of more than twenty Icelandic upper secondary schools. In recent years, his research has mainly focused on the use of local studies in teaching and the history of Icelandic schools. 


\section{Heimildir}

Alta. (e.d.). Vefsjá.

Alpingistidindi $1889 \mathrm{C}$.

Barnafræðsla árið 1914-15. (1918). Hagskýrslur Íslands, 16. Reykjavík: Hagstofa Íslands.

Barnafræðsla árin 1909-1914. (1922). Hagskýrslur Íslands, 30. Reykjavík: Hagstofa Íslands.

Barnafræðsla árin 1916-20. (1920-1923). Hagskýrslur Íslands, 35. Reykjavík: Hagstofa Íslands.

Barnafræðsluskýrslur árin 1920-1966. (1967). Hagskýrslur Íslands, aukaflokkur, 1. Reykjavík: Hagstofa Íslands.

Björk Ingimundardóttir. (2019). Prestaköll, sóknir og prófastsdami á Íslandi 1-2. Reykjavík: Pjóðskjalasafn Íslands.

Bragi Guðmundsson. (1992). Héraðsstjórn i Húnapingi: Saga sýslunefndanna i Húnavatnssýslu 1872-1907 og Austur-Húnavatnssýslu 1908-1988. Akureyri: Sýslunefnd Austur-Húnavatnssýslu.

Erla Hulda Halldórsdóttir. (1997). Að vera sjálfstæð: Ímyndir, veruleiki og frelsishugmyndir kvenna á 19. öld. Saga, 35, bls. 57-94.

Gils Guðmundsson. (1988). Garðar Gíslason stórkaupmaður. Í Gils Guðmundsson (ritstjóri), Deir settu svipá öldina: Íslenskir athafnamenn 2 (bls. 141-157). Reykjavík: Iðunn.

Guðmundur Finnbogason. (1905). Skýrsla um freðslu barna og unglinga veturinn 1903-1904. Reykjavík: [án útgefanda].

Guðmundur Sigurður Jóhannsson og Magnús Björnsson. (1999). Ettir Austur-Húnvetninga 1-4. Reykjavík: Mál og mynd.

Hagstofa Íslands. (e.d.). Mannfö̈ldi eftir sveitarfélögum 1901-1990. Sótt 7. maí 2020 af https://px.hagstofa.is/ pxis/pxweb/is/Ibuar/Ibuar_mannfjoldi_2_byggdir_sveitarfelogeldra/MAN02120.px.

Íslensk erfðagreining og Friðrik Skúlason. (1997-2020). Íslendingabók.

Jóhann Hjaltason. (1952). Strandasýsla. Í Arbók (Ferðafélag Îslands). Reykjavík: Ferðafélag Íslands.

Jón Guðnason. (1955). Strandamenn: Eviskrár 1703-1953. Reykjavík: Höfundur.

Kvennaskóli Húnvetninga 1879-1939: Minningarrit. (1939). Reykjavík: Skólaráð Kvennaskóla Húnvetninga.

Landshagsskýrslur fyrir Ísland 1903 I.

Loftur Guttormsson. (1992). Farskólahald í sextíu ár (1890-1950). Nokkrir megindrættir. Uppeldi og menntun 1, bls. 207-222.

Loftur Guttormsson. (2008a). Fræðsluhefðin: kirkjuleg heimafræðsla. Í Loftur Guttormsson (ritstjóri), Almenningsfrałsla á Íslandi 1880-2007, 1: Skólahald i ba og sveit (bls. 21-35). Reykjavík: Háskólaútgáfan.

Loftur Guttormsson. (2008b). Pjóðfélagsbreytingar og menntamál. Í Loftur Guttormsson (ritstjóri), Almenningsfraðsla à Íslandi 1880-2007, 1: Skólahald i ba og sveit (bls. 38-53). Reykjavík: Háskólaútgáfan.

Loftur Guttormsson. (2008c). Sjálfsprottnir skólar. Í Loftur Guttormsson (ritstjóri), Almenningsfređsla á Íslandi 1880-2007, 1: Skólahald i ba og sveit (bls. 56-71). Reykjavík: Háskólaútgáfan.

Loftur Guttormsson. (2008d). Barnakennarar: starfskjör menntun og staða. Í Loftur Guttormsson (ritstjóri), Almenningsfraosla á Íslandi 1880-2007, 1: Skólahald i ba og sveit (bls. 126-141). Reykjavík: Háskólaútgáfan.

Lýður Björnsson. (1972-1979). Saga sveitarstjórnar á Íslandi 1-2. Reykjavík: Almenna bókafélagið.

Lög um fræðslu barna nr. 59/1907.

Magnús Björnsson. (1953). Alpýðufræðarar I: Frímann barnakennari. Hlin, 35, bls. 78-83.

Magnús Björnsson. (1957a). Frímann barnakennari. Í Magnuis Björnsson, Mannaferðir og fornar slódir (bls. 103-123). Akureyri: Bókaforlag Odds Björnssonar.

Magnús Björnsson. (1957b). Jakob Frimannsson. Í Magnús Björnsson, Mannaferðir og fornar slóðir (bls. 124-146). Akureyri: Bókaforlag Odds Björnssonar.

Magnús Jónsson. (1957). Landshöfðingjatímabilið. Í Saga Íslendinga: 9. bindi. Tímabilið 1871-1903, landshöfdingjatímabilið. Fyrri hluti, pjódmál - atvinnuvegir. Reykjavík: Menntamálaráð og Pjóðvinafélag.

Manntalsvefur Pjóðskjalasafns Îslands. (2020). Sótt af http://manntal.is/. 
Ólafur P. Kristjánsson (ritstjóri). (1958-1965). Kennaratal á Íslandi 1-2. Reykjavík: Oddi.

Ólafur P. Kristjánsson og Sigrún Harðardóttir (ritstjórar). (1985-1988). Kennaratal á Íslandi 1-5 (2. útgáfa). Reykjavík: Oddi.

Ólöf Garðarsdóttir. (2010). Barnakennarar á Íslandi um aldamótin 1900. Ráðstefnurit Netlu - Menntakvika 2010. Sótt af http://hdl.handle.net/1946/7810.

Pétur Jónsson. (1947). Strandamannabók (Guðni Jónsson bjó til prentunar). Reykjavík: Ísafoldarprentsmiðja. Skýrsla um barnaskóla 1888-89. (1890). Tímarit um uppeldi og menntamál, 3, bls. 104-112.

Skýrsla um sveitakennslu, eða umgangskennslu, sem borguð er úr landssjóði 1889-1890. (1891). Tímarit um uppeldi og menntamál, 4, bls. 94-95.

Skýrsla um sveitakennslu, sem greiddur hefur verið styrkur til úr landssjóði 1890-1891. (1892). Tímarit um uppeldi og menntamál, 5, bls. 92-94.

Snorri Porsteinsson. (2009). Barna- og unglingafradsla i Mýrasýslu 1880-2007. Akranes: Uppheimar.

Stjórnartídindi fyrir Ísland $1889 \mathrm{~B}$.

Pjóðskjalasafn Íslands [PÍ] (skráðar eru allar öskjur sem geyma gögn sem notuð eru á einn eða annan hátt, hvort sem til peirra er vitnað í tilvísunum eða ekki). Lh. er skammstöfun fyrir Landshöfðingjasafn og Stv. er skammstöfun fyrir Skjalasafn stiftsyfirvalda):

Lh. Nr. II. 1903-1904. Skýrslur um fræðslu barna og unglinga veturinn 1903-1904. Ísafjarðarprófastsdæmi - Suður-Múlaprófastsdæmi.

Lh. N.J. 1888-1892. Ár 1888. N nr. 480-559.

Lh. N.J. 1888-1892. Ár 1889. N nr. 630-699.

Lh. N.J. 1888-1892. Ár 1890. N nr. 570-589.

Lh. N.J. Ár 1891. N nr. 636-649.

Lh. N.J. Ár 1894. N nr. 730-809.

Lh. Nr. XII. Ár 1894-1905. Sveitakennarar Strandasýsla 1894-1905.

Lh. Nr. XIII. Ár 1894-1905. Sveitakennarar Húnavatnssýsla 1894-1899.

Lh. Nr. XIV. Ár 1894-1905. Sveitakennarar Húnavatnssýsla 1900-1905.

Stv. D.I. Nr. 342-345.

Bragi Guðmundsson. (2020).

Um sveitakennara í Strandasýslu og Húnavatnssýslu 1887-1905.

Netla - Veftímarit um uppeldi og menntun: Sérrit 2020 - Menntavika 2020.

Sótt af http://netla.hi.is/serrit/2020/menntavika_2020/01.pdf

DOI: https://doi.org/10.24270/serritnetla.2020.7 